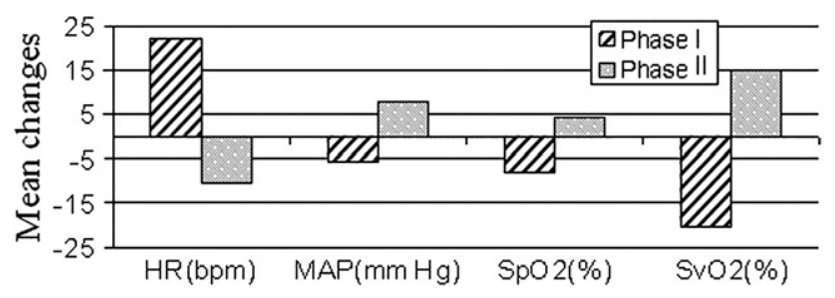

FIGURE 2. Mean changes in systemic and extracorporeal membrane oxygenation parameters during phases I and II. $H R$, Heart rate; $M A P$, mean arterial pressure; $\mathrm{SpO}_{2}$, arterial oxygen saturation; $\mathrm{SvO}_{2}$, venous oxygen saturation.

in $\mathrm{HbO}_{2}$ concentrations could be explained by a compensatory arterial dilation.

We demonstrate that multichannel optical topographic analysis can provide information on regional cerebral hemodynamics and oxygenation in patients supported by ECMO. Simultaneous measurement of systemic and cerebral $\mathrm{HbO}_{2}$ and $\mathrm{HHb}$ concentrations can help elucidate mechanisms related to the response of the brain during changes in ECMO and cardiopulmonary bypass flows.
In this patient modest changes in ECMO flows appear to present a significant hemodynamic challenge to cerebral circulation. Further work is necessary to support application of this novel brain-monitoring technology in cardiac theaters and intensive care units, and we now have a protocol to further investigate regional brain oxygenation in these patients.

\section{References}

1. Nollert G, Shin'oka T, Jonas RA. Near infrared spectrophotometry of the brain in cardiovascular surgery. Thorac Cardiovasc Surg. 1998;46:167-75.

2. Austin EH 3rd, Edmonds HL Jr, Auden SM, Seremet V, Niznik G, Sehic A, et al. Benefit of neurophysiologic monitoring for pediatric cardiac surgery. $J$ Thorac Cardiovasc Surg. 1997; 114:707-15.

3. Hirsch JC, Charpie JR, Ohye RG, Gurney JG. Near infrared spectroscopy (NIRS) should not be standard of care for postoperative management. Semin Thorac Cardiovasc Surg Pediatr Card Surg Annu. 2010;13:51-4.

4. Tortoriello TA, Stayer SA, Mott AR, McKenzie ED, Fraser CD, Andropoulos DB et al. A noninvasive estimation of mixed venous oxygen saturation using nearinfrared spectroscopy by cerebral oximetry in pediatric cardiac surgery patients. Paediatr Anaesth. 2005;15:495-503.

5. Papademetriou MD, Tachtsidis I, Leung TS, Elliott MJ, Hoskote A Elwell CE. Cerebral and peripheral tissue oxygenation in children supported on ECMO for cardio-respiratory failure. Adv Exp Med Biol. 2010;662: 447-53.

\title{
Seven-year outcome of pulmonary valve autograft replacement of the mitral valve in an infant
}

\author{
Tomohito Kanzaki, MD, ${ }^{\mathrm{a}}$ Masaaki Yamagishi, MD, PhD, ${ }^{\mathrm{a}}$ Masafumi Yashima, MD, ${ }^{\mathrm{a}}$ and

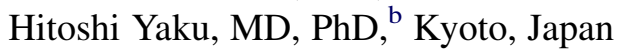

Pulmonary autograft replacement of the mitral valve ${ }^{1}$ appears to be a useful alternative for children with irreparable mitral valve disease. Long-term results, however, have yet to be reported. We previously reported a case of mitral valve replacement with a Gore-Tex-reinforced (W. L. Gore \& Associates, Inc, Flagstaff, Ariz) pulmonary autograft in a child. ${ }^{2}$ In this report, we described the fate of the pulmonary autograft 7 years after that operation.

\footnotetext{
From the Department of Pediatric Cardiovascular Surgery, ${ }^{a}$ Children's Research Hospital, Kyoto Prefectural University of Medicine, and the Division of Cardiovascular Surgery, ${ }^{\mathrm{b}}$ Department of Surgery, Kyoto Prefectural University of Medicine, Kyoto, Japan. Disclosures: Authors have nothing to disclose with regard to commercial support. Received for publication Aug 25, 2010; revisions received Dec 14, 2010; accepted for publication Jan 24, 2011; available ahead of print March 7, 2011.

Address for reprints: Masaaki Yamagishi, MD, PhD, Department of Pediatric Cardiovascular Surgery, Children's Research Hospital, Kyoto Prefectural University of Medicine, 465 Kajii-cho, Kawaramachi, Hirokoji, Kamigyo-ku, Kyoto 602-8566 Japan (E-mail: myama@koto.kpu-m.ac.jp).

J Thorac Cardiovasc Surg 2011;141:e33-5

$0022-5223 / \$ 36.00$

Copyright (C) 2011 by The American Association for Thoracic Surgery doi:10.1016/j.jtcvs.2011.01.049
}

\section{CLINICAL SUMMARY}

A girl with a partial atrioventricular septal defect and severe mitral regurgitation underwent pulmonary autograft replacement of the mitral valve when 11 months old. The pulmonary autograft was anastomosed to an appropriately sized Gore-Tex expanded polytetrafluoroethylene (ePTFE) graft. $^{2}$ The ePTFE felt strip was looped around and sewn onto the outer surface of the Gore-Tex graft as a sewing cuff. The pulmonary autograft with the ePTFE external cylinder was inserted into the mitral annulus, and the ePTFE felt band was anastomosed to the mitral annulus. The implanted valve did not protrude into either the left ventricle or the left atrium. The operation was successful, and the patient was further treated with medications including diuretics, digoxin, and an angiotensin-converting enzyme inhibitor for treatment of chronic heart failure. Six years after the operation, an echocardiogram showed mild mitral regurgitation but no significant mitral stenosis. A follow-up cardiac catheterization demonstrated growth of fibrous tissue causing the 


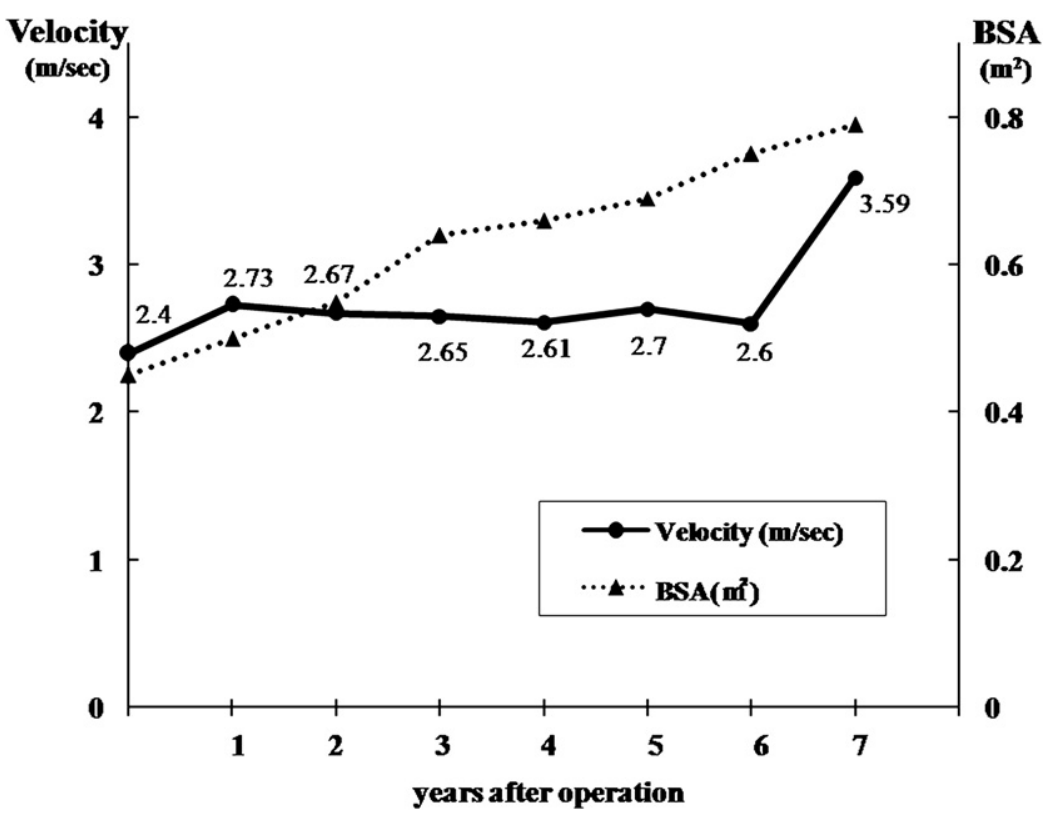

FIGURE 1. Changes of flow velocity across the pulmonary autograft in the mitral position. Despite body weight and body surface area (BSA) gains, the velocity was relatively stable until 6 years after pulmonary autograft replacement of the mitral valve. The velocity was rapidly increased, however, 7 years after the operation.

subaortic stenosis, which was believed to be the cause of her chronic heart failure. We initially planned a resection of the subaortic fibrous tissue. While the patient was waiting for her operation, however, another echocardiogram demonstrated worsening mitral regurgitation, with the peak blood flow velocity across the mitral valve rapidly increasing from $2.6 \mathrm{~m} / \mathrm{s}$ to $3.59 \mathrm{~m} / \mathrm{s}$ (Figure 1). Also, the ascending aorta-left ventricle pressure gradient increased from $60 \mathrm{~mm} \mathrm{Hg}$ to $90 \mathrm{~mm} \mathrm{Hg}$. The patient's left ventricular ejection fraction was $73 \%$. We therefore decided to perform a reoperation 7 years after her initial pulmonary autograft replacement of the mitral valve. At that time, her body weight had increased from $7 \mathrm{~kg}$ to $20 \mathrm{~kg}$, and her body surface area was $0.78 \mathrm{~m}^{2}$. The mitral annular diameter was $14 \mathrm{~mm}$ ( $52 \%$ of normal value) according to echocardiography.

After establishment of cardiopulmonary bypass, the pulmonary autograft was harvested by cutting the PTFE felt suturing cuff wrapped around the pulmonary autograft. Each of the cusps of the pulmonary autograft was slightly thickened; however, no deformity or calcification was detected. Mobility and coaptation of the cusps were well maintained (Figure 2). Subaortic stenosis was caused by overgrowth of the fibrous ring tissue. The ePTFE outer cylinder of the pulmonary autograft was not directly involved with the subaortic stenosis. The subaortic fibrous ring was completely resected. Both aortic and mitral annuli were enlarged by cutting the mitralaortic fibrous continuity. A 23-mm ATS valve (ATS Medical, Inc, Minneapolis, Minn) was implanted at mitral position, and an 18-mm ATS valve was implanted at the aortic position.

\section{DISCUSSION}

Because of the demands of patient growth and the long-term durability concerns regarding prosthetic valves, the mitral valve should be repaired as early as possible once regurgitation has been detected in children. When there is intractable mitral deformity, however, such as dysplastic leaflets or a severe abnormality of the subvalvular apparatus, we have no choice but to replace the mitral valve with prosthetic materials. There is no appropriate prosthetic valve for infants that has both growth potential and lifelong durability. Sizing of the prosthetic valve is also very limited, and anticoagulation therapy for mechanical valves is a relatively difficult problem in the pediatric population. Finally, biologic valves have a tendency toward early degeneration and calcification in pediatric patients. ${ }^{3}$

As an alternative procedure, replacement of the mitral valve with a pulmonary autograft is a useful option for intractable pediatric mitral valve disease, ${ }^{1,2,4,5}$ especially in children with narrow mitral annulus. During the procedure, reinforcement of the pulmonary outer wall is necessary to retain a suitable pulmonary valve configuration. If the pulmonary autograft with a round annulus is implanted into an elliptical mitral annulus without reinforcement of the pulmonary wall, the pulmonary annulus may distort elliptically and the pulmonary commissures may bend inward against the inner pressure of the left ventricle, resulting in valve dysfunction. 

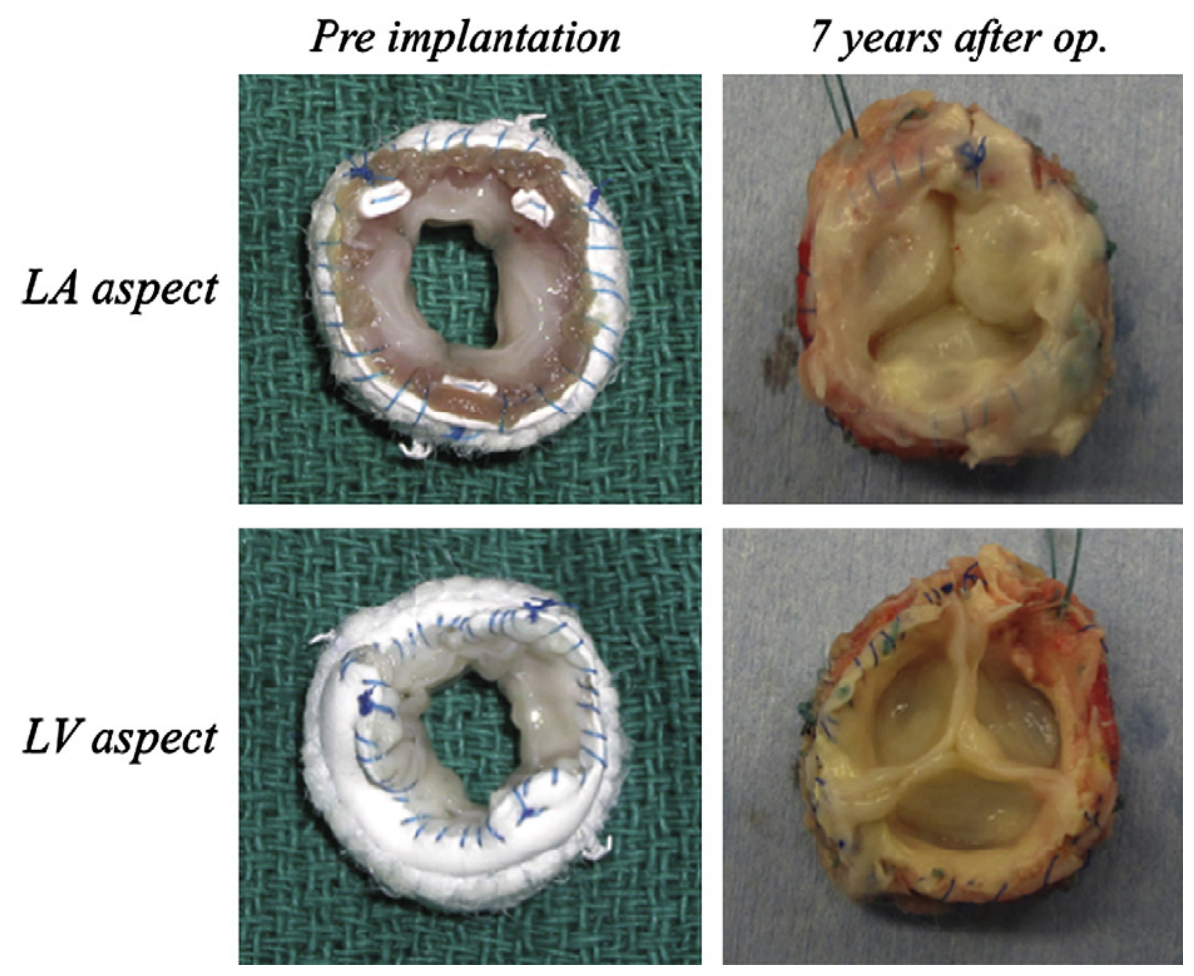

FIGURE 2. Left, Preimplantation views of the pulmonary autograft bearing the expanded polytetrafluoroethylene external cylinder. Right, Resected pulmonary autograft 7 years after pulmonary autograft replacement of the mitral valve (op.). The pulmonary autograft showed no significant constriction or deformation. Each of the cusps was a little thickened, but the mobility and coaptation were well preserved. $L A$, Left atrial; $L V$, left ventricular.

On the other hand, the growth potential of the pulmonary autograft is compromised by this prosthetic material reinforcement. Although reoperation seems inevitable because of relative mitral stenosis with an increase in body weight, the pulmonary autograft in this case maintained an ideal configuration and a satisfactory performance for 7 years without anticoagulation. Reinforcement with a cylinder of ePTFE is an efficient procedure to maintain pulmonary autograft configuration and function.

In conclusion, pulmonary autograft replacement of the mitral valve is a useful alternative procedure for intractable congenital mitral valve disease in young infants.

\section{References}

1. Kabbani S, Jamil H, Nabhani F, Hamoud A, Katan K, Sabbagh N, et al. Analysis of 92 mitral pulmonary autograft replacement (Ross II) operations. J Thorac Cardiovasc Surg. 2007;134:902-98.

2. Yamagishi M, Shuntoh K, Matsushita T, Fujiwara K, Shinkawa T, Miyazaki T, et al. Mitral valve replacement by a Gore-Tex reinforced pulmonary autograft in a child. J Thorac Cardiovasc Surg. 2003;126:1218-9.

3. Vohra HA, Laker S, Stumper O, De Giovanni JV, Wright JG, Barron DJ, et al. Predicting the performance of mitral prostheses implanted in children under 5 years of age. Eur J Cardiothorac Surg. 2006;29:688-92.

4. Kumar AS, Talwar S, Gupta A. Mitral valve replacement with the pulmonary autograft: midterm results. $J$ Thorac Cardiovasc Surg. 2009;138: 359-64.

5. Mitchell MB, Maharajh GS, Bielefeld MR, DeGroff CG, Clarke DR. Emergency pulmonary autograft mitral valve replacement in a child. Ann Thorac Surg. 2001; $72: 251-3$. 